\title{
The Roles of Angiotensin II Receptors in the Portosystemic Collaterals of Portal Hypertensive and Cirrhotic Rats
}

\author{
Hui-Chun Huang ${ }^{a, c}$ Ching-Chih Chang ${ }^{b, c}$ Sun-Sang Wang ${ }^{a, c}$ Fa-Yauh Lee ${ }^{a, c}$ \\ Tzu-Hua Teng ${ }^{a}$ Jing-Yi Lee ${ }^{a, e}$ Han-Chieh Lin ${ }^{a, c}$ Chiao-Lin Chuangb, c \\ Shou-Dong Lee ${ }^{a, c}$ \\ Divisions of a Gastroenterology and ${ }^{b}$ General Medicine, Department of Medicine, Taipei Veterans General Hospital, \\ 'Faculty of Medicine, and d Department and Institute of Pharmacology, National Yang-Ming University, \\ Taipei, Taiwan
}

\section{Key Words}

Angiotensin II - Angiotensin receptor · Cirrhosis •

Endothelial nitric oxide synthase $\cdot$ Perfusion $\cdot$

Collateralization

\begin{abstract}
Background/Aims: In liver cirrhosis/portal hypertension, collaterals as varices may bleed and are influenced by vasoresponsiveness. An angiotensin blockade ameliorates portal hypertension but the influence on collaterals is unknown. Methods: Portal hypertension and cirrhosis were induced by portal vein (PVL) and common bile duct ligation (BDL). Hemodynamics, real-time PCR of angiotensin II receptors $\left(A T_{1} R, A T_{2} R\right.$ ) in the left adrenal vein ( $L A V$, sham) and splenorenal shunt derived from $L A V(P V L, B D L)$ were performed. With an in situ collateral perfusion model, angiotensin II vasoresponsiveness with different preincubations was evaluated: (1) vehicle; (2) $\mathrm{AT}_{1} \mathrm{R}$ blocker losartan; (3) losartan plus nonselective nitric oxide synthase (NOS) inhibitor ( $\mathrm{N}^{\omega}$-nitroL-arginine); (4) $\mathrm{AT}_{2} \mathrm{R}$ blocker PD123319; (5) PD123319 plus $\mathrm{N}^{\omega}$-nitro-L-arginine; (6) $\mathrm{N}^{\omega}$-nitro-L-arginine, and (7) losartan plus inducible NOS inhibitor aminoguanidine. Results: LAV
\end{abstract}

$A T_{1} R$ and $A T_{2} R$ expression decreased in PVL and BDL rats. Losartan attenuated angiotensin II-elicited vasoconstriction but PD123319 had no effect. $\mathrm{N}^{\omega}$-nitro-L-arginine but not aminoguanidine reversed the losartan effect. Conclusions: Angiotensin receptors are downregulated in the collateral vessel of portal hypertensive and cirrhotic rats. The $A T_{1} R$ blockade attenuates the angiotensin II vasoconstrictive effect, suggesting $A T_{1} R$ mediates collateral vasoconstriction and the influence of $A T_{2} R$ is negligible. The lack of aminoguanidine influence indicates that endothelial NOS participates in the losartan effect.

Copyright $\odot 2012$ S. Karger AG, Basel

\section{Introduction}

Renin-angiotensin system is pivotal in circulatory function and body fluid homeostasis [1] in which angiotensin II plays a key role [2]. The vascular effects of an-

Hui-Chun Huang and Ching-Chih Chang contributed equally to this work.

\section{KARGER}

Fax +4161306 1234 E-Mail karger@karger.ch www.karger.com (c) 2012 S. Karger AG, Basel

$1018-1172 / 12 / 0492-0160 \$ 38.00 / 0$

Accessible online at:

www.karger.com/jvr
Dr. Fa-Yauh Lee

Division of Gastroenterology, Department of Medicine

Taipei Veterans General Hospital

No. 201, Sec 2, Shih-Pai Road, Taipei 11217 (Taiwan)

Tel. +88622875 7500, E-Mail fylee@vghtpe.gov.tw 
giotensin II are mediated by two subtypes of receptors, type $1\left(\mathrm{AT}_{1} \mathrm{R}\right)$ and $2\left(\mathrm{AT}_{2} \mathrm{R}\right)$ [3]. Previous studies have indicated that angiotensin II mainly induced vasoconstriction via $\mathrm{AT}_{1} \mathrm{R}$ whereas $\mathrm{AT}_{2} \mathrm{R}$ mediated vasodilatation $[4$, 5]. Siragy et al. [6] and Siragy and Carey [7] discovered that $\mathrm{AT}_{2} \mathrm{R}$ stimulation engendered a vasodilator cascade composed of bradykinin, nitric oxide (NO) and guanosine cyclic 3',5'-monophosphate. However, the interactions between angiotensin II and NO is rather complex. It has been reported that angiotensin II stimulates $\mathrm{NO}$ synthesis via $\mathrm{AT}_{2} \mathrm{R}$ in endothelial cells [8]. $\mathrm{AT}_{1} \mathrm{R}$ activation also elicited endothelial NO synthesis in rat carotid arteries [9], although the extent of $\mathrm{AT}_{1} \mathrm{R}$-mediated $\mathrm{NO}$ release is not sufficient to overcome the overriding contractile response exerted by the same receptor [10].

A recent study has indicated that angiotensin II may elevate portal pressure via the enhancement of the adrenergic vasoconstrictory effect and a direct contractile influence on stellate cells [11]. On the other hand, a worse splanchnic vascular contractile response to angiotensin II in portal hypertensive rats has been found [12], suggesting its diverse actions in different vascular beds. In liver cirrhosis and portal hypertension, the portosystemic collaterals develop in response to the increased intrahepatic resistance, trying to divert stagnant portal venous blood flow to systemic circulation. Among them, gastroesophageal varices have been notorious for massive hemorrhage with high morbidity and mortality. The portosystemic collateral vascular response to vasoconstrictors is, actually, pivotal in the control of gastroesophageal variceal hemorrhage. Furthermore, since portal pressure is influenced by portal inflow, intrahepatic resistance and portosystemic collateral vascular resistance, the collaterals also participate in the control of portal pressure. Nevertheless, the influence of angiotensin II in this distinct vascular bed has not been evaluated. We herein surveyed the presence and expression levels of angiotensin II receptors in the most prominent intra-abdominal portosystemic collateral vessel, splenorenal shunt that is derived from the left adrenal vein in normal rats [13]. Furthermore, the collateral vascular responses to angiotensin II influenced by different angiotensin II receptor antagonists in portal hypertensive and cirrhotic rats were evaluated.

\section{Animals and Methods}

\section{Animal Model}

Male Sprague-Dawley rats (300-350 g) were maintained at $24^{\circ} \mathrm{C}$ with a 12 -hour light-dark cycle and free access to food and water. Surgery and hemodynamic studies were performed under ketamine hydrochloride anesthesia (100 mg/kg; i.m.). Portal hypertension was induced by partial portal vein ligation (PVL) [14] and liver cirrhosis by common bile duct ligation (BDL) [15-17], respectively. Corresponding sham groups received sham operations without ligations and were treated in the same way. To avoid coagulation defects, BDL rats received weekly vitamin $\mathrm{K}$ injections ( $50 \mu \mathrm{g} / \mathrm{kg}$; i.m.). The study was been approved by the Taipei Veterans General Hospital Animal Committee. The principles of laboratory animal care [Guide for the Care and Use of Laboratory Animals, DHEW publication No. (NIH) 85-23, rev. 985, Office of Science and Health Reports, DRR/NIH, Bethesda, Md., USA.] were followed.

In situ Perfusion Preparation

As previously described [18, 19], in brief, both jugular veins were cannulated with 16-gauge Teflon cannulas as outlets of perfusate. The inlet was an 18-gauge Teflon cannula inserted in the superior mesenteric vein. To exclude the liver from perfusion, the portal vein was tied. The animal was transferred into a chamber $\left(37 \pm 0.5^{\circ} \mathrm{C}\right)$. Perfusion was started via the mesenteric cannula by a roller pump (model 505S; Watson-Marlow Ltd., Falmouth, UK) with Krebs solution equilibrated with $95 \%$ (v/v) $\mathrm{O}_{2}$ and $5 \%$ (v/v) $\mathrm{CO}_{2}$ by a silastic membrane lung [20]. Pneumothorax was created by opening slits through the diaphragm to increase pulmonary arterial resistance and prevent the perfusate from entering the left heart. Experiments were performed 25 min after starting perfusion at a constant rate of $20 \mathrm{ml} / \mathrm{min}$ for PVL rats and 12 $\mathrm{ml} / \mathrm{min}$ for BDL rats. As the flow rate was kept constant, the measured perfusion pressure reflected collateral vascular resistance. Only one concentration-response curve was performed in each preparation and the contracting capability was challenged with a 125-mM potassium chloride solution after testing the experimental agents.

\section{Measurement of Systemic and Portal Hemodynamics}

The right femoral arteries and mesenteric vein were cannulated with PE-50 catheters connected to Spectramed DTX transducers (Spectramed Inc., Oxnard, Calif., USA). The external zero reference was at the level of the midportion of the rat. Continuous recordings of mean arterial pressure, heart rate and portal pressure were performed on a multichannel recorder (model RS 3400, Gould Inc., Cupertino, Calif., USA) [21, 22].

\section{Total Ribonucleic Acid Isolation}

Total ribonucleic acid (RNA) was extracted from the splenorenal shunt, the most prominent intra-abdominal portosystemic collateral vessel in the cirrhotic and portal hypertensive rat, with the RNeasy Mini Kit (Qiagen GmbH, Hilden, Germany). Only undegraded RNA free of genomic DNA contamination was used. The extracted RNA was quantified by UV absorbance at $260 \mathrm{~nm}$, quickly frozen on ice and stored at $-80^{\circ} \mathrm{C}$ for real-time PCR analysis.

\section{Real-Time Quantitative RT-PCR}

One microgram of total RNA was reverse-transcribed to cDNA with Superscript II reverse transcriptase and poly dT priming (Life Technologies, Rockville, Md., USA). Quantitative RT-PCR was carried out on a LightCycler (LightCycler 480, Roche Diagnostics, Mannheim, Germany) and a standard LightCycler amplification cycle protocol was established for each gene. 
The primers are: $\beta$-actin: $5^{\prime}$-TTGTAACCAACTGGGACGATATGG-3' (sense), 5'-GATCTTGATCTTCATGGTGCTAGG-3' (antisense); inducible NO synthase (iNOS): 5'-AGACGCACAGGCAGAGGT-3' (sense), 5'-AGGCACACGCAATGATGG-3 (antisense); endothelial NOS (eNOS): 5'-CTGCTGCCCGAGATATCTTC-3' (sense), 5'-CAGGTACTGCAGTCCCTCCT-3' (antisense); $\mathrm{AT}_{1} \mathrm{R}: 5^{\prime}$-ACTCTTTCCTACCGCCCTTC-3' (sense); 5'-TTAGCCCAAATGGTCCTCTG-3' (antisense); AT 2 R: 5' -CAATCTGGCTGTGGCTGACTT-3' (sense), 5'-TGCACATCACAGGTCCAAAGA-3' (antisense) [23, 24]. A total volume of $18 \mu \mathrm{l}$ of LightCycler master mix was pipetted into LightCycler glass capillaries and $2 \mu \mathrm{l}$ of the cDNA product (diluted tenfold) was added as a PCR template. The capillaries were placed in the LightCycler carousel and centrifuged in a specific LightCycler centrifuge. The first segment of the amplification cycle consisted of a denaturation program of $95^{\circ} \mathrm{C}$ for $10 \mathrm{~min}$. The second segment consisted of denaturation $\left(95^{\circ} \mathrm{C}\right.$ for $\left.15 \mathrm{~s}\right)$, primer annealing $\left(58^{\circ} \mathrm{C}\right.$ for $\left.5 \mathrm{~s}\right)$, elongation $\left(72^{\circ} \mathrm{C}\right.$ for $\left.10 \mathrm{~s}\right)$ and a quantification program repeated for 40 cycles. The third segment consisted of a melting curve program $\left(95^{\circ} \mathrm{C}\right.$ for $0 \mathrm{~s}, 57^{\circ} \mathrm{C}$ for $15 \mathrm{~s}$ and a linear temperature transition at $0.05^{\circ} \mathrm{C} / \mathrm{s}$ from 57 to $95^{\circ} \mathrm{C}$ with continuous fluorescence acquisition). The final segment consisted of a cooling program to $40^{\circ} \mathrm{C}$. An internal housekeeping gene, $\beta$-actin, was used to normalize the differences in RNA isolation, RNA degradation and the efficiencies of the RT. The abundance of mRNA was determined by real-time RT-PCR normalized to the abundance of $\beta$ actin mRNA. LightCycler analysis software (Roche Diagnostics) allowed the quantitative analysis.

\section{Study Design}

Systemic and portal hemodynamics were evaluated on the 8th day after PVL and the 43rd day after BDL. Following this two studies were performed: first, real-time PCR analysis of $\mathrm{AT}_{1} \mathrm{R}$ and $\mathrm{AT}_{2} \mathrm{R}$ of splenorenal shunt in PVL, BDL and their corresponding sham groups; second, with an in situ collateral perfusion model and different preincubations $(30 \mathrm{~min}$ before the beginning throughout the whole course of the concentration-response relationship study), the collateral vascular responses to angiotensin II $\left(3 \times 10^{-10}, 10^{-9}, 3 \times 10^{-9}, 10^{-8}, 3 \times 10^{-8}, 10^{-7} \mathrm{M}\right)$ in PVL and BDL rats were evaluated. This was done in 7 steps: (1) Krebs solution (vehicle control); (2) $\mathrm{AT}_{1} \mathrm{R}$ blocker, losartan $\left(3 \times 10^{-5} \mathrm{M}\right)$; (3) losartan plus a nonselective NOS inhibitor $\left(\mathrm{N}^{\omega}\right.$-nitro-L-arginine, NNA, $\left.10^{-4} \mathrm{M}\right)$; (4) $\mathrm{AT}_{2} \mathrm{R}$ blocker, PD123319 (10-6 M); (5) PD123319 plus NNA; (6) NNA, and (7) losartan plus aminoguanidine, a selective iNOS inhibitor $\left(10^{-4} \mathrm{M}\right)$.

\section{Drugs}

Angiotensin II, losartan, PD123319, NNA, aminoguanidine and reagents for Krebs solution were purchased from Sigma Chemical Co. (St. Louis, Mo., USA). All solutions were freshly prepared on the days of experiment.

\section{Statistical Analysis}

Results are expressed as mean \pm standard error of the mean (mean \pm SEM). The changes in perfusion pressure $(\mathrm{mm} \mathrm{Hg}$ ) over the baseline were calculated for each concentration in each preparation. The concentration-response curves were fitted by nonlinear regression using the computer software Prism (Graph Pad Software Inc., San Diego, Calif., USA). Differences between the dose-response curves were analyzed by two-way ANOVA for re-
Table 1. Body weight and baseline hemodynamics in PVL rats

\begin{tabular}{lrlrll}
\hline & $\mathrm{n}$ & $\begin{array}{l}\text { BW } \\
\mathrm{g}\end{array}$ & $\begin{array}{l}\text { MAP } \\
\mathrm{mm} \mathrm{Hg}\end{array}$ & $\begin{array}{l}\text { HR } \\
\text { beats/min }\end{array}$ & $\begin{array}{l}\mathrm{PP} \\
\mathrm{mm} \mathrm{Hg}\end{array}$ \\
\hline Krebs & 16 & $330 \pm 5$ & $107 \pm 4$ & $378 \pm 15$ & $15.5 \pm 0.7$ \\
Lo & 7 & $335 \pm 16$ & $107 \pm 8$ & $355 \pm 24$ & $17.5 \pm 1.4$ \\
Lo + NNA & 6 & $329 \pm 7.2$ & $91 \pm 8$ & $356 \pm 31$ & $14.1 \pm 1.1$ \\
Lo + AG & 7 & $293 \pm 12$ & $108 \pm 7$ & $280 \pm 239$ & $20.5 \pm 1.2$ \\
NNA & 6 & $303 \pm 16$ & $108 \pm 4$ & $427 \pm 10$ & $15.6 \pm 1.2$ \\
PD & 7 & $313 \pm 6$ & $100 \pm 5$ & $334 \pm 22$ & $15.5 \pm 1.8$ \\
PD + NNA & 8 & $322 \pm 7$ & $100 \pm 4$ & $341 \pm 18$ & $16.2 \pm 0.8$ \\
\hline
\end{tabular}

$\mathrm{BW}=$ Body weight MAP = mean arterial pressure; $\mathrm{HR}=$ heart rate; $\mathrm{PP}=$ portal pressure; Krebs = Krebs solution (vehicle control); Lo = losartan; $A G=$ aminoguanidine; $P D=$ PD123319. All $\mathrm{p}>0.05$.

Table 2. Body weight and baseline hemodynamics in BDL rats

\begin{tabular}{lllcll}
\hline & $\mathrm{n}$ & $\begin{array}{l}\mathrm{BW} \\
\mathrm{g}\end{array}$ & $\begin{array}{l}\mathrm{MAP} \\
\mathrm{mm} \mathrm{Hg}\end{array}$ & $\begin{array}{l}\mathrm{HR} \\
\text { beats/min }\end{array}$ & $\begin{array}{l}\mathrm{PP} \\
\mathrm{mm} \mathrm{Hg}\end{array}$ \\
\hline Krebs & 9 & $311 \pm 16$ & $93 \pm 6$ & $283 \pm 23$ & $17.2 \pm 0.8$ \\
Lo & 7 & $302 \pm 17$ & $96 \pm 7$ & $283 \pm 22$ & $18.1 \pm 2.8$ \\
Lo + NNA & 6 & $298 \pm 16$ & $96 \pm 10$ & $280 \pm 16$ & $17.5 \pm 1.6$ \\
Lo + AG & 6 & $293 \pm 12$ & $108 \pm 7$ & $280 \pm 18$ & $20.5 \pm 1.2$ \\
NNA & 8 & $284 \pm 14$ & $99 \pm 6$ & $280 \pm 17$ & $21.3 \pm 1.9$ \\
PD & 8 & $292 \pm 22$ & $106 \pm 8$ & $302 \pm 25$ & $17.1 \pm 1.4$ \\
PD + NNA & 8 & $308 \pm 15$ & $97 \pm 6$ & $271 \pm 15$ & $17.5 \pm 1.6$ \\
\end{tabular}

All $\mathrm{p}>0.05$.

peated measures using SPSS 15.0.1 for Windows (SPSS Inc., Chicago, Ill., USA). For comparison of mRNA expression, the unpaired Student $t$ test was used. A two-tailed $\mathrm{p}<0.05$ was considered significant.

\section{Results}

\section{Baseline Hemodynamics}

Tables 1 and 2 show the body weights and baseline hemodynamics of PVL and BDL rats before the perfusion studies. Body weight, heart rate, mean arterial pressure and portal pressure were similar among these groups $(\mathrm{p}>0.05)$.

\section{Splenorenal Shunt Angiotensin Receptors mRNA Expression}

Compared with the sham rats, $\mathrm{AT}_{2} \mathrm{R}$ mRNA expressions were significantly decreased in PVL rats $\left(\mathrm{AT}_{2} \mathrm{R} / \beta\right.$ - 
Fig. 1. $A T_{1} R$ and $A T_{2} R$ mRNA expressions in splenorenal shunts of PVL (a, b), BDL (c, d) and corresponding sham-operated rats. Compared with the corresponding sham groups, $\mathrm{AT}_{2} \mathrm{R}$ mRNA expressions were significantly decreased in PVL rats and $\mathrm{AT}_{1} \mathrm{R}$ and $\mathrm{AT}_{2} \mathrm{R}$ decreased in BDL rats.
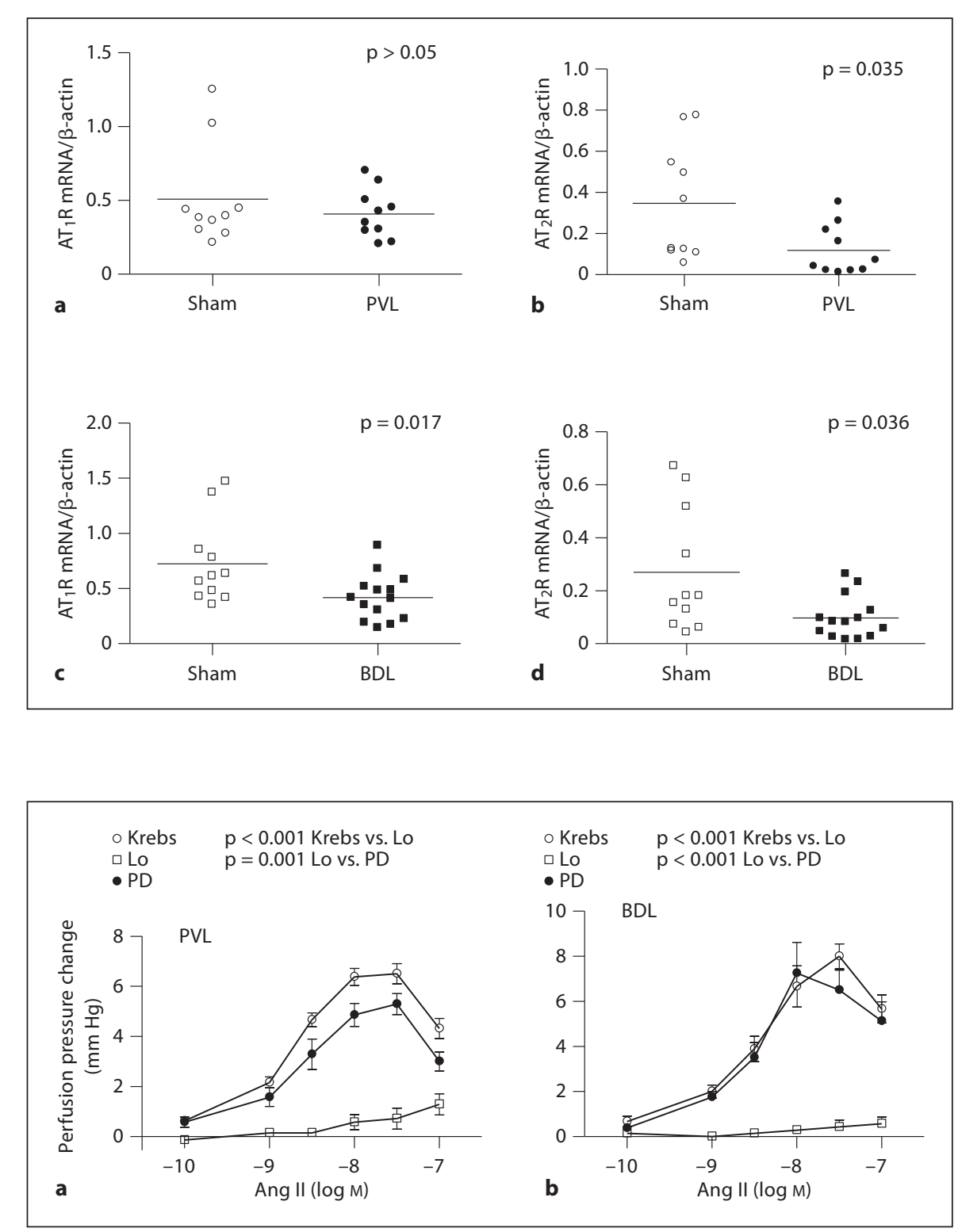

Fig. 2. Concentration-response curves to angiotensin (Ang) II in portosystemic collateral vascular beds of PVL (a) or BDL (b) rats when preincubated with Krebs solution (vehicle control), losartan (Lo), or PD123319 (PD), expressed as absolute increase over the baseline value. a In PVL rats, compared with the vehicle group, losartan significantly decreased the perfusion pressure changes to angiotensin II. b In BDL rats, compared with the vehicle group, losartan significantly reduced the perfusion pressure changes to angioten$\sin$ II. actin: $0.347 \pm 0.089$ vs. $0.118 \pm 0.039, p=0.035$, fig. $1 b)$. Although $\mathrm{AT}_{1}$ mRNA expression was lower in the PVL group, it did not reach a statistical significance $\left(\mathrm{AT}_{1} \mathrm{R} / \beta\right.$ actin: 0.508 vs. $0.409, \mathrm{p}=0.421$, fig. $1 \mathrm{a})$. Both $\mathrm{AT}_{1} \mathrm{R}$ and $\mathrm{AT}_{2} \mathrm{R}$ mRNA expressions were significantly decreased in $\mathrm{BDL}$ rats $\left(\mathrm{AT}_{1} \mathrm{R} / \beta\right.$-actin: $0.724 \pm 0.114$ vs. $0.417 \pm 0.056$, $\mathrm{p}=0.017$, fig. $1 \mathrm{c} ; \mathrm{AT}_{2} \mathrm{R} / \beta$-actin: $0.270 \pm 0.070$ vs. 0.097 $\pm 0.022, \mathrm{p}=0.036$, fig. $1 \mathrm{~d})$. There was no significant difference between $\mathrm{AT}_{1} \mathrm{R}$ expression of PVL and BDL rats and between $\mathrm{AT}_{2} \mathrm{R}$ expression of PVL and BDL rats $(\mathrm{p}>$ 0.05).

Angiotensin and Portosystemic Collateral Response
Concentration-Response Relationships to Angiotensin II with $A T_{1}$ R or $A T_{2} R$ Blockade in PVL or BDL Rats

Figure 2 shows the concentration-response curves of portosystemic collaterals to angiotensin II with different preincubations in PVL rats: Krebs solution (control), losartan, or PD123319. Compared with the control group, in PVL rats losartan significantly decreased the collateral vascular bed perfusion pressure changes to angioten$\sin$ II ( $p<0.001)$. The perfusion pressure changes elicited by losartan was also lower than PD123319 ( $\mathrm{p}=0.001)$. PD123319 did not significantly influence the perfusion pressure changes to angiotensin II (fig. 2a). 


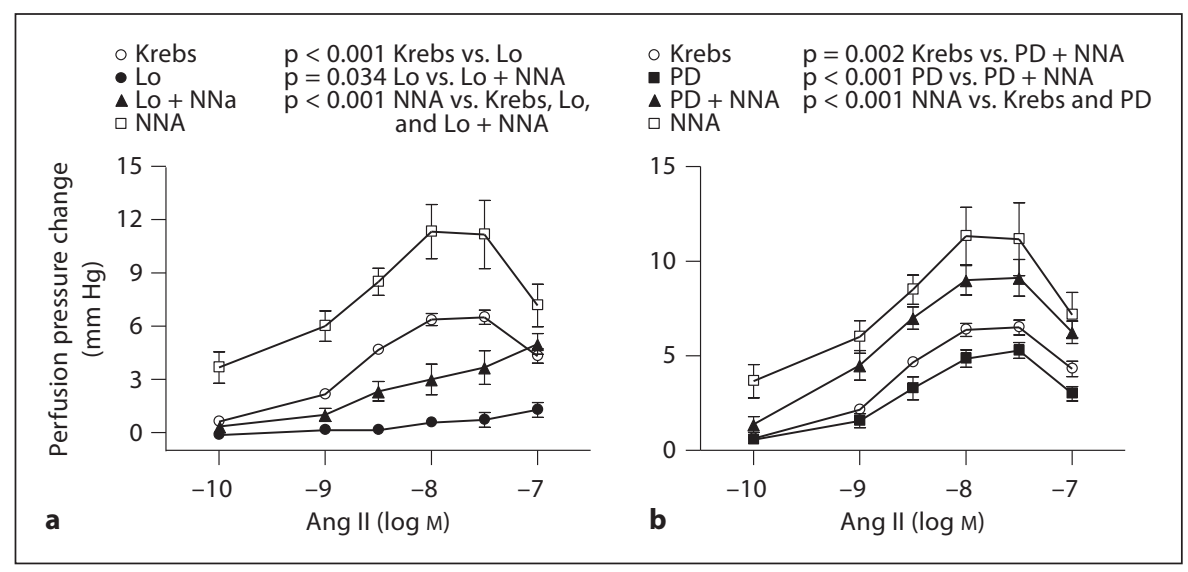

Fig. 3. Concentration-response curves to angiotensin (Ang) II in portosystemic collateral vascular beds of PVL rats with the following preincubations: Krebs solution (vehicle control), losartan (Lo), losartan plus NNA, or NNA (a) and Krebs solution (vehicle control), PD123319 (PD), PD123319 plus NNA, or NNA (b), expressed as absolute increase over the baseline value. a Losartan plus NNA significantly reversed the attenuation of pressure response to an- giotensin II by losartan alone. In addition, NNA exerted the highest perfusion pressure changes in all groups, which was attenuated by losartan. b PD123319 plus NNA significantly enhanced the pressure response to angiotensin II by PD123319 alone. NNA exerted the highest perfusion pressure changes in all groups which were not influenced by PD123319.

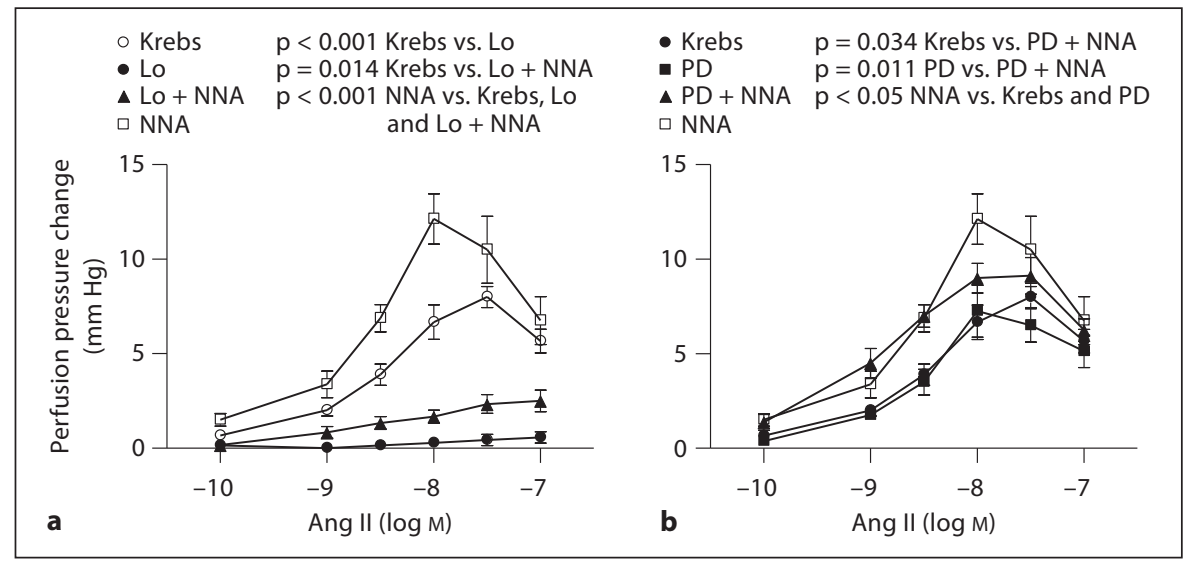

Fig. 4. Concentration-response curves to angiotensin (Ang) II in portosystemic collateral vascular beds of BDL rats with the following preincubations: Krebs solution (vehicle control), losartan (Lo), losartan plus NNA, or NNA (a) and Krebs solution (vehicle control), PD123319 (PD), PD123319 plus NNA, or NNA (b), expressed as absolute increase over the baseline value. a Losartan plus NNA elicited higher perfusion pressure changes than those by losartan alone, but did not reach statistical significance (all $p>0.05$ ). NNA exerted the highest perfusion pressure changes in all groups, which was attenuated by losartan. b PD123319 plus NNA significantly enhanced the pressure response to angiotensin II by PD123319 alone. NNA exerted the highest perfusion pressure changes in all groups which were not influenced by PD123319 $(\mathrm{p}>0.05)$.
In BDL rats, compared with the control group, losartan significantly reduced the perfusion pressure changes to angiotensin II $(p<0.001)$. Losartan elicited lower perfusion pressure changes than PD123319 ( $\mathrm{p}<0.001$ ). PD123319 did not significantly influence the perfusion pressure changes to angiotensin II (fig. 2b).
Concentration-Response Relationships to Angiotensin II with $A T_{1}$ and/or NNA/Aminoguanidine Blockade in PVL Rats

Figure 3 a depicts the concentration-response curves to angiotensin II in PVL rats with different preincubations: Krebs solution (control), losartan, losartan plus NNA or 
Fig. 5. Concentration-response curves to angiotensin (Ang) II in portosystemic collateral vascular beds of PVL (a) and BDL (b) rats, preincubated with Krebs solution (vehicle control), losartan (Lo), or losartan plus aminoguanidine (AG), expressed as absolute increase over the baseline value. The perfusion pressure changes to angiotensin II influenced by losartan were not modified by aminoguanidine, an iNOS inhibitor, both in PVL (a) and BDL (b) rats.

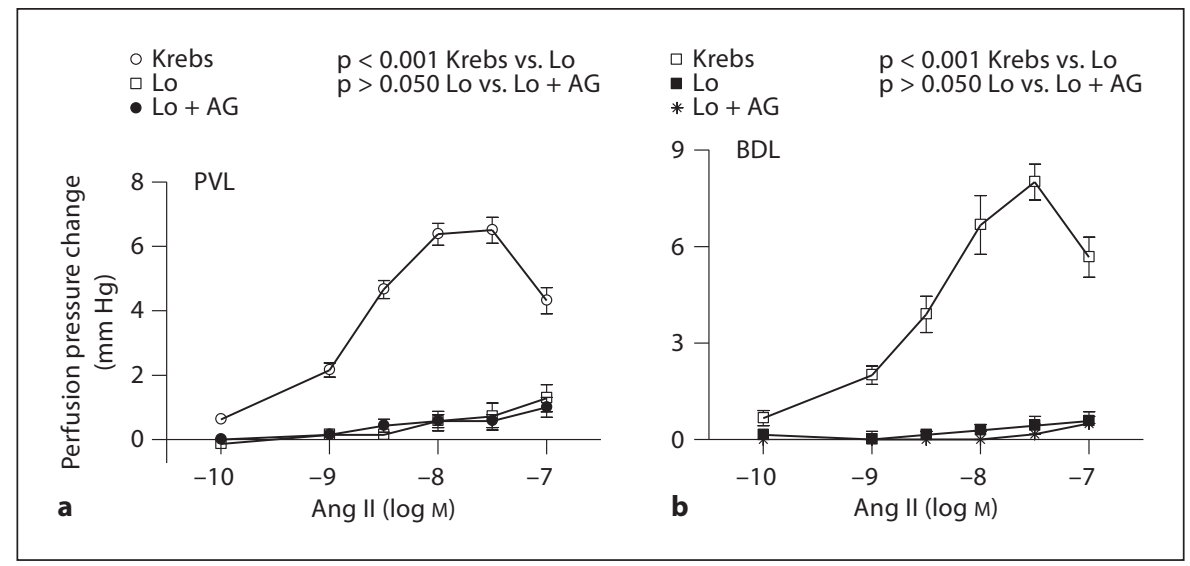

NNA alone. Losartan plus NNA significantly reversed the attenuation of pressure response to angiotensin II by losartan alone $(\mathrm{p}=0.034)$. NNA exerted the highest perfusion pressure changes in all groups whereas it was attenuated by losartan co-preincubation $(\mathrm{p}<0.001)$. The perfusion pressure changes to angiotensin II influenced by losartan was not modified by the addition of aminoguanidine, an iNOS inhibitor (fig. 5a).

Concentration-Response Relationships to Angiotensin

II with $\mathrm{AT}_{2}$ and/or NNA Blockade in PVL Rats

Figure $3 \mathrm{~b}$ shows the concentration-response curves to angiotensin II in PVL rats with different preincubations: Krebs solution (control), PD123319, PD123319 plus NNA or NNA alone. PD123319 plus NNA significantly enhanced the pressure response to angiotensin II by PD123319 alone ( $<0.001)$. NNA exerted the highest perfusion pressure changes in all groups which were not influenced by PD123319 co-preincubation.

Concentration-Response Relationships to Angiotensin

II with $A T_{1}$ and/or NNA/Aminoguanidine Blockade in BDL Rats

Figure 4a depicts the concentration-response curves to angiotensin II in BDL rats with different preincubations: Krebs solution (control), losartan, losartan plus NNA or NNA alone. Losartan plus NNA elicited higher perfusion pressure changes than those by losartan alone, but did not reach statistical significance $(\mathrm{p}>0.05)$. NNA exerted the highest perfusion pressure changes in all groups whereas it was attenuated by losartan co-preincubation $(\mathrm{p}<0.001)$. The perfusion pressure changes to angiotensin II influenced by losartan was not modified by the addition of aminoguanidine, an iNOS inhibitor (fig. 5b).

Angiotensin and Portosystemic Collateral Response
Concentration-Response Relationships to Angiotensin

II with $\mathrm{AT}_{2}$ and/or NNA Blockade in BDL Rats

Figure $4 \mathrm{~b}$ demonstrates the concentration-response curves to angiotensin II in BDL rats with different preincubations: Krebs solution (control), PD123319, PD123319 plus NNA or NNA alone. PD123319 plus NNA significantly enhanced the pressure response to angiotensin II by PD123319 alone ( $\mathrm{p}=0.011)$. NNA exerted the highest perfusion pressure changes in all groups which were not influenced by PD123319 co-preincubation.

\section{Discussion}

The current study has five major findings: in portosystemic collaterals of PVL and BDL rats, (1) $\mathrm{AT}_{1} \mathrm{R}$ and $\mathrm{AT}_{2} \mathrm{R}$ are present and more downregulated than those of the corresponding control groups; (2) the $\mathrm{AT}_{1} \mathrm{R}$ blockade with losartan alleviates angiotensin II-induced vasoconstrictive effects; (3) PD123319, an $\mathrm{AT}_{2} \mathrm{R}$ blocker, does not significantly influence the collateral vascular responsiveness to angiotensin II; (4) in the presence of NOS inhibition with NNA, losartan attenuates NNAenhanced collateral vasoconstrictive response to angiotensin II, and (5) the selective iNOS inhibitor aminoguanidine did not influence the collateral vascular responsiveness modified by losartan. Since the vascular NO synthesis is mainly mediated via iNOS and eNOS, a crucial role of eNOS in the losartan effect is suggested. However, the potential influence of another constitutive NOS, the neuronal NOS, should be taken into consideration.

In the portosystemic collateral vascular bed, the downregulation of $\mathrm{AT}_{2} \mathrm{R}$ in PVL rats and $\mathrm{AT}_{1} \mathrm{R}$ and $\mathrm{AT}_{2} \mathrm{R}$ 
in BDL rats is noted. An increase in angiotensin II level as the result of the activation of the renin-angiotensin system is evidenced in cirrhosis and correlates with portal hypertension $[25,26]$. However, splanchnic hyposensitivity to angiotensin II is common in cirrhotic and portal hypertensive states. It occurs despite elevated plasma levels of angiotensin II $[27,28]$. Downregulation of AT receptors, either qualitative or quantitative, may play a role in the vascular hyposensitivity. Hennenberg et al. [29] have proposed that in humans and rats with cirrhosis, hepatic arterial and aortic hypocontractility to angiotensin II is due to enhanced $\beta$-arrestin-2 binding to receptors, resulting in $\mathrm{AT}_{1} \mathrm{R}$ desensitization without affecting $\mathrm{AT}_{1} \mathrm{R}$ expression. Nevertheless, the nature of the conductance vessels may not be representative of the collateral resistance vessels. Our current data suggest that the downregulation of angiotensin receptors may pave the way for hyporesponsiveness to angiogtensin II in portosystemic collaterals.

The current finding that the $\mathrm{AT}_{1} \mathrm{R}$ blockade decreased the portosystemic collateral vasoconstrictive response to angiotensin II in PVL and BDL rats indicates that $\mathrm{AT}_{1} \mathrm{R}$ mediates the angiotensin II-induced vasoconstriction in this vascular bed. This is consistent with the previous report that angiotensin II-induced vasoconstriction was mediated through $\mathrm{AT}_{1} \mathrm{R}$, which could be reversed by losartan [30]. Regarding the relevant studies on portal systems, it has been found that losartan, an $\mathrm{AT}_{1} \mathrm{R}$ antagonist, elicited a significant reduction in the hepatic venous pressure gradient [31]. The portal hypotensive effect of losartan was attributed to the reduction in intrahepatic vascular resistance. Arroyo et al. [32] also reported that saralasin significantly decreased portal pressure in cirrhotic patients. In that study, those who showed a substantial reduction in portal pressure demonstrated a marked reduction of the hepatic vascular resistance. Interestingly, another study showed that losar$\tan$ at $3 \mathrm{mg} / \mathrm{kg}$ intravenously reduced portal pressure via an increase in splanchnic vascular resistance and decrease in portal inflow. However, at higher doses, losartan reduced portal pressure by a decrease in peripheral vascular resistance [33]. Since portal pressure is determined by the net effects of splanchnic vascular resistance, intrahepatic resistance and portosystemic collateral vascular resistance, the attenuation of the angiotensin II pressor effect by losartan on collaterals may contribute, at least partly, to its portal hypotensive action.

The $\mathrm{AT}_{2} \mathrm{R}$ blockade with PD123319 did not significantly influence the collateral vasoconstrictive response to angiotensin II. In the portal system, Fernandes et al. [34] showed that angiotensin II contracted mesenteric venules and portal veins by activating both $\mathrm{AT}_{1} \mathrm{R}$ and $\mathrm{AT}_{2} \mathrm{R}$. Pelet et al. [35] also demonstrated that angiotensin II-induced contraction in rat portal vein was mediated through $\mathrm{AT}_{1} \mathrm{R}$ and $\mathrm{AT}_{2} \mathrm{R}$ activation, in which $\mathrm{AT}_{1} \mathrm{R}$ was responsible for about $80 \%$ of the maximal contractile response. In other vascular beds, $\mathrm{AT}_{2} \mathrm{R}$ stimulation induced vasoconstriction in untreated mesenteric resistance arteries from spontaneously hypertensive rats [36]. Furthermore, in young hypertensive rats, an angiotensin II-induced contraction was decreased by PD123319 [37]. In rats with hemorrhagic shock, selective stimulation of $\mathrm{AT}_{2} \mathrm{R}$ in the presence of the $\mathrm{AT}_{1} \mathrm{R}$ blockade increased cerebrovascular resistance elicited by angiotensin II [38]. Moreover, in the perfused hydronephrotic kidney, PD 123319 reduces angiotensin II-induced contraction of intralobular renal arteries [39]. Such a vasoconstrictive action in the renal circulation may be mediated by cytochrome P450 metabolites such as 20-HETE [40,41]. Although contradictory results showed that stimulation of $\mathrm{AT}_{2} \mathrm{R}$ induces relaxation in several vascular territories $[42,43]$, the vascular action of $\mathrm{AT}_{2} \mathrm{R}$ seems to be diverse and influenced by pathologic conditions, hemodynamic derangements and multiple substances.

In the current study, the attenuation of angiotensin II-induced vasoconstriction by losartan was reversed by NNA, but not aminoguanidine, an inducible NOS inhibitor, suggesting the participation of eNOS in the mechanism. Furthermore, NNA plus losartan attenuated the enhanced angiotensin II vasoconstrictive effect exerted by NNA alone, especially in PVL rats. This is in agreement with a previous study which demonstrated that the reduction of angiotensin II-mediated vasoconstriction elicited by losartan can be reversed by NO inhibition [30]. The authors postulated that in the presence of $\mathrm{AT}_{1} \mathrm{R}$ antagonists, angiotensin II binds to unblocked $\mathrm{AT}_{2} \mathrm{R}$ and then stimulates $\mathrm{NO}$ synthesis [30]. A similar finding showed that the $\mathrm{AT}_{1} \mathrm{R}$ blockade in patients with coronary artery disease led to endothelial $\mathrm{NO}$ release which was mediated by $\mathrm{AT}_{2} \mathrm{R}$ stimulation [44]. This is supported by the finding that $\mathrm{AT}_{1} \mathrm{R}$ activation increased endothelial NO synthesis in rat isolated carotid arteries [9].

In summary, $\mathrm{AT}_{1} \mathrm{R}$ and $\mathrm{AT}_{2} \mathrm{R}$ are present and downregulated in the portosystemic collaterals of portal hypertensive and cirrhotic rats. The $\mathrm{AT}_{1} \mathrm{R}$ blockade attenuates the pressor effects of angiotensin II in the collaterals, suggesting that $\mathrm{AT}_{1} \mathrm{R}$ mediates the vasoconstrictive effect. Endothelial NOS activation plays a role in the $\mathrm{AT}_{1} \mathrm{R}-$ 
induced response. The findings indicate the vascular hyposensitivity to angiotensin II related to receptor downregulation and the lack of influence of $\mathrm{AT}_{2} \mathrm{R}$ in this vascular bed in portal hypertension and cirrhosis.

\section{Acknowledgements}

The authors gratefully acknowledge Yi-Chou Chen for his excellent technical assistance. This work was supported by grants from the National Science Council (NSC97-2314-B-075-030MY2) and Taipei Veterans General Hospital (V97C1-050), Taiwan.

\section{References}

1 Whitebread S, Mele M, Kamber B, de Gasparo M: Preliminary biochemical characterization of two angiotensin II receptor subtypes. Biochem Biophys Res Commun 1989; 163:284-291.

2 Sealey JE, Laragh JH: The renin-angiotensin-aldosterone system for normal regulation of blood pressure and sodium and potassium homeostasis; in Laragh JH, Brenner BM (eds): Hypertension: Pathophysiology, Diagnosis, and Management. New York, Raven Press, 1995, pp 1763-1796.

-3 Chiu AT, Herblin WF, McCall DE, Ardecky RJ, Carini DJ, Duncia JV, Pease LJ, Wong PC, Wexler RR, Johnson AL: Identification of angiotensin II receptor subtypes. Biochem Biophys Res Commun 1989;165:196-203.

$\checkmark 4$ Widdop RE, Matrougui K, Levy BI, Henrion $\mathrm{D}: \mathrm{AT}_{2}$ receptor-mediated relaxation is preserved after long-term AT1 receptor blockade. Hypertension 2002;40:516-520

5 Carey RM, Howell NL, Jin XH, Siragy HM: Angiotensin type-2 receptor-mediated hypotension in angiotensin type-1 receptorblocked rats. Hypertension 2001;38:12721277.

-6 Siragy HM, Jaffa AA, Margolius HS, Carey RM: Renin-angiotensin system modulates renal bradykinin production. Am J Physiol Reg Int Comp Physiol 1996;271:R1090R1095.

7 Siragy HM, Carey RM: The subtype-2( $\left.\mathrm{AT}_{2}\right)$ angiotensin receptor mediates renal production of nitric oxide in conscious rats. J Clin Invest 1997; 100:264-269.

-8 Wiemer G, Scholkens BA, Wagner A, Heitsch $\mathrm{H}$, Linz W: The possible role of angiotensin II subtype $\mathrm{AT}_{2}$ receptors in endothelial cells and isolated ischemic rat hearts. J Hypertension 1993;11:S234-S235.

-9 Caputo L, Benessiano J, Boulanger CM, Levy BI: Angiotensin II increases cGMP content via endothelial angiotensin II $\mathrm{AT}_{1}$ subtype receptors in the rat carotid artery. Arterioscler Thromb Vasc Biol 1995;15:1646-1651.

$\checkmark 10$ Zwart AS, Davis EA, Widdop RE: Modulation of $\mathrm{AT}_{1}$ receptor-mediated contraction of rat uterine artery by $\mathrm{AT}_{2}$ receptors. Br J Pharmacol 1998;125:1429-1436.

-11 Bataller R, Ginès P, Nicolás JM, Görbig MN, Garcia-Ramallo E, Gasull X, Bosch J, Arroyo $\mathrm{V}$, Rodés J: Angiotensin II induces contraction and proliferation of human hepatic stellate cells. Gastroenterology 2000;118:11491156.
12 Wu Y, Li SS, Campbell KA, Sitzmann JV Modulation of splanchnic vascular sensitivity to angiotensin II. Surgery 1991;110:162168.

13 Halvorsen JF, Myking AO: The porto-systemic collateral pattern in the rat. Eur Surg Res 1974;6:183-195.

14 Chojkier M, Groszmann RJ: Measurement of the portal-systemic shunting in the rat by using $\gamma$-labeled microspheres. Am J Physiol 1981;240:G371-G375.

15 Franco D, Gigou M, Szekely AM, Bismuth H: Portal hypertension after bile duct obstruction: effect of the bile diversion on portal pressure in the rat. Arch Surg 1979;114: 1064-1067.

16 Cameron GR, Hasan SM: Disturbances of structure and function in the liver as the result of biliary obstruction. J Pathol Bacteriol 1958;75:33-49.

17 Kountouras J, Billing BH, Scheuer PJ: Prolonged bile duct ligation obstruction: a new experimental model of cirrhosis in the rat. $\mathrm{Br}$ J Exp Pathol 1984;65:305-311.

18 Chan CC, Lee FY, Wang SS, Chang FY, Lin HC, Chu CJ, Tai CC, Lai IN, Lee SD: Effects of vasopressin on portal-systemic collaterals in portal hypertensive rats: role of nitric oxide and prostaglandin. Hepatology 1999;30: 630-635.

19 Chan CC, Wang SS, Lee FY, Chang FY, Lin HC, Hou MC, Huang HC, Lee SD: Effects of endothelin-1 on portal-systemic collaterals of common bile duct-ligated cirrhotic rats. Eur J Clin Invest 2004;34:290-296.

20 Hamilton RL, Berry MN, Williams MC, Severinghaus EM: A simple and inexpensive membrane 'lung' for small organ perfusions. J Lipid Res 1974;15:182-186.

-21 Lee FY, Colombato LA, Albillos A, Groszmann RJ: Administration of N omega-nitroL-arginine ameliorates portal-systemic shunting in portal-hypertensive rats. Gastroenterology 1993;105:1464-1470.

22 Lee FY, Wang SS, Tsai YT, Lin HJ, Lin HC Chu CJ, Wu SL, Tai CC, Lee SD: Aminoguanidine corrects hyperdynamic circulation without ameliorating portal hypertension and portal hypertensive gastropathy in anesthetized portal hypertensive rats. J Hepatol 1997;26:687-693.
23 Lee JH, Xia S, Ragolia L: Upregulation of $\mathrm{AT}_{2}$ receptor and iNOS impairs angiotensin IIinduced contraction without endothelium influence in young normotensive diabetic rats. Am J Physiol 2008;295:R144-R154.

$\checkmark 24$ Liu LM, Dubick MA: Hemorrhagic shockinduced vascular hyporeactivity in the rat: relationship to gene expression of nitric oxide synthase, endothelin-1, and select cytokines in corresponding organs. J Surg Res 2005;125:128-136.

25 Bosch J, Arroyo V, Betriu A, Mas A, Carrilho F, Rivera F, Navarro-Lopez F, Rodes J: Hepatic hemodynamics and the renin-angiotensin-aldosterone system in cirrhosis. Gastroenterology 1980;78:92-99.

26 García-Pagán JC, Bosch J, Rodés J: The role of vasoactive mediators in portal hypertension. Semin Gastrointest Dis 1995;6:140-147.

27 Schepke M, Heller J, Paschke S, Thomas J, Wolff M, Neef M, Malago M, Molderings GJ, Spengler U, Sauerbruch T: Contractile hyporesponsiveness of hepatic arteries in humans with cirrhosis: evidence for a receptor-specific mechanism. Hepatology 2001;34:884888 .

28 Groszmann RJ: Hyperdynamic circulation of liver disease 40 years later: pathophysiology and clinical consequences. Hepatology 1994;20:1359-1363.

29 Hennenberg M, Trebicka J, Biecker E, Schepke M, Sauerbruch T, Heller J: Vascular dysfunction in human and rat cirrhosis: role of receptor-desensitizing and calcium-sensitizing proteins. Hepatology 2007;45:495506.

30 Maeso R, Rodrigo E, Muñoz-Garcia R, Navarro-Cid J, Ruilope LM, Lahera V, Cachofeiro V: Losartan reduces constrictor responses to endothelin-1 and the thromboxane A2 analogue in aortic rings from spontaneously hypertensive rats: role of nitric oxide. J Hypertension 1997; 15:16771684.

31 Schneider AW, Kalk JF, Klein CP: Effect of losartan, an angiotensin II receptor antagonist, on portal pressure in cirrhosis. Hepatology 1999;29:334-339.

32 Arroyo V, Bosch J, Mauri M, Ribera F, Navarro-Lopez F, Rodes J: Effect of angiotensin-II blockade on systemic and hepatic haemodynamics and on the renin-angiotensinaldosterone system in cirrhosis with ascites. Eur J Clin Invest 1981;11:221-229. 
-33 Heller J, Shiozawa T, Trebicka J, Hennenberg M, Schepke M, Neef M, Sauerbruch T: Acute haemodynamic effects of losartan in anaesthetized cirrhotic rats. Eur J Clin Invest 2003;33:1006-1012.

-34 Fernandes L, Loiola RA, Tostes RCA, Nigro D, Fortes ZB, de Carvalho MHC: Angiotensin II-induced venoconstriction involves both $\mathrm{AT}_{1}$ and $\mathrm{AT}_{2}$ receptors and is counterbalanced by nitric oxide. Peptides 2005;26: 2458-2463.

-35 Pelet C, Mironneau C, Rakotoarisoa L, Neuilly G: Angiotensin II receptor subtypes and contractile responses in portal vein smooth muscle. Eur J Pharmacol 1995;279: 15-24.

>36 You D, Loufrani L, Baron C, Levy BI, Widdop RE, Henrion D: High blood pressure reduction reverses angiotensin II type 2 receptor-mediated vasoconstriction into vasodilation in spontaneously hypertensive rats. Circulation 2005;111:1006-1011.
37 Touyz RM, Endemann D, He G, Li JS, Schiffrin EL: Role of $\mathrm{AT}_{2}$ receptors in angiotensin II-stimulated contraction of small mesenteric arteries in young SHR. Hypertension 1999;33:366-372.

38 Naveri L, Stromberg C, Saavedra JM: Angiotensin II $\mathrm{AT}_{2}$ receptor stimulation increases cerebrovascular resistance during hemorrhagic hypotension in rats. Regul Pept 1994; 52:21-29.

39 Hayashi K, Suzuki H, Saruta T: Segmental differences in angiotensin receptor subtypes in interlobular artery of hydronephrotic rat kidneys. Am J Physiol 1993;265:F881-F885.

40 Muller C, Endlich K, Helwig JJ: $\mathrm{AT}_{2}$ antagonist-sensitive potentiation of angiotensin IIinduced constriction by $\mathrm{NO}$ blockade and its dependence on endothelium and P450 eicosanoids in rat renal vasculature. Br J Pharmacol 1998;124:946-952.
41 Endlich K, Muller C, Barthelmebs M, Helwig JJ: Role of shear stress in nitric oxide-dependent modulation of renal angiotensin II vasoconstriction. Br J Pharmacol 1999;127: 1929-1935.

42 Carey RM, Jin X-H, Siragy HM: Role of the angiotensin $\mathrm{AT}_{2}$ receptor in blood pressure regulation and therapeutic implications. Am J Hypertens 2001;14:98S-102S.

43 Dimitropoulou C, White RE, Fuchs L, Zhang H, Catravas JD, Carrier GO: Angiotensin II relaxes microvessels via the $\mathrm{AT}_{2}$ receptor and $\mathrm{Ca}^{2+}$-activated $\mathrm{K}^{+}\left(\mathrm{Bk}_{\mathrm{ca}}\right)$ channels. Hypertension 2001;37:301-307.

44 Hornig B, Landmesser U, Kohler C, Ahlersmann D, Spiekermann S, Christoph A, Tatge $\mathrm{H}$, Drexler H: Comparative effect of ace inhibition and angiotensin II type 1 receptor antagonism on bioavailability of nitric oxide in patients with coronary artery disease: role of superoxide dismutase. Circulation 2001; 103:799-805. 